\title{
Occupier responses to sustainable real estate: what's next?
}

\begin{abstract}
Purpose - The purpose of this paper is two-fold. Primarily, it examines the relationship between sustainable buildings and occupiers, by summarising the key extant literature. Secondarily, the paper proposes avenues for future research relating to the impact of sustainability on corporate real estate strategy.
\end{abstract}

Design/methodology/approach - The paper reviews over ninety relevant publications related to sustainability, real estate market responses and corporate real estate, focussing on the role and response of occupiers. The approach concentrates on occupier strategies, specifically considering influences such as corporate social responsibility (CSR), landlord tenant relationships, the changing occupier role and the 'circle of blame'.

Findings - In recent years, literature has increasingly begun to reflect nuances in occupier responses to sustainable, prime, office real estate, with some conflicting findings as to the importance of sustainability. Location remains the dominant consideration in decision making for occupiers, but sustainability is key to CSR and 'value-add' in certain sectors. More effective use of sustainable buildings requires improved communication between landlord and tenant. Our review demonstrates that challenges still remain in relation to the 'circle of blame'. More research needs to be done in relation to the emergence of sustainability in the non-prime and retail sectors.

Originality I value - Through collating key literature in this topical research area, the paper provides a critical review of occupier responses to sustainable real estate, and therefore a fuller understanding of emerging market practices. Additionally, it suggests future research directions.

Keywords - Sustainable buildings, Occupier perceptions, CRE strategy, Decision making, Circle of blame.

Paper type - Literature review.

\section{Introduction}

This paper reviewed over ninety publications related to sustainability, and discusses the most relevant to real estate market responses and corporate real estate, focussing on the occupier perspective. It is the first paper to collate and review the extant literature which reflects on the complex role of the occupier specifically, in the delivery of sustainable real estate.

The notion of what 'sustainability' means is open to varied, nuanced interpretations and perceptions, which change in time and vary between locations as well as countries. There are in excess of 500 definitions of 'sustainability' in circulation (Dixon et al, 2008) and there is a lack of consistency in terms of what the concept means to those working in built environment professions (Wilkinson, 2015). However, in the main, interpretations stem from the Brundtland report's (1987) definition, which accounts for the social, economic and environmental impacts of development, the so-called 'triple bottom line' (TBL) (Elkington, 1997). Concomitant to the broadening of how 'sustainability' is defined and applied, the real estate industry has been actively responding to the need for not only environmentally progressive buildings, but buildings which play a key role in occupier, investor and developer strategies within a wider political agenda.

Indeed, it is not just sustainability which is subject to a spectrum of definitions, but also what is meant by 'sustainable building'. Much of the real estate literature is specifically linked to the 
'how to' of sustainable construction through best practice industry guidelines (RICS 2013a, 2013b, 2009), industry toolkits (BBP, 2012; 2013) and relevant benchmarks (GRESB, 2015; REESTI, 2014), which relate the benefits and ongoing developments regarding sustainability to the industry. Much of this work has an international perspective (RICS, 2014), although the adoption and development of sustainable building practices and therefore the extant literature, is concentrated on studying particular commercial real estate markets. The UK (Fuerst \& McAllister, 2011a; Shiers, 1999), USA (DeLisle et al, 2013; Kats, 2003), Scandinavia (Andelin et al, 2015; Vimpari \& Junnilla, 2014), Australia (Warren-Myers, 2012a; Bowman \& Wills, 2008) and New Zealand (Levy \& Peterson, 2013; Bond \& Perrett, 2012), are the vanguard nations when it comes to the development, adaptation and valuation of sustainable real estate.

Within these core markets, assessment methods and ratings have been adopted to explicitly demonstrate the environmental performance of buildings, such as BREEAM (UK led best practice certification), LEED (USA) and Green Star certifications (Australia \& New Zealand). Although the rating calculation methods are explicit, the interpretation of these ratings is subjective, and, the way these are understood is not consistent (Haapio \& Viitaniemi, 2008). However, there is a market tendency to consider buildings with high ratings for environmental performance as sustainable (Spinks, 2015; Van de Wetering \& Wyatt, 2011), and typically prime real estate (Rydin, 2016). The benefit of environmental ratings and the inferred 'green value' to investors and developers has been investigated in literature since the turn of the century, with occupier perceptions coming more to the fore in recent years. Are highly rated, sustainable buildings desired by occupiers and used in sustainable ways; what role does 'sustainability' play in the occupier market? Evolving occupier responses to sustainability discussed in this paper include the business case for occupation, corporate social responsibility (CSR), workplace productivity, green leases, landlord tenant relationships and CRE decision making.

Initially, a wider reflection on sustainability literature to date is presented in the following sections, which link in key papers on theoretical perspectives, investment, and development research to set the context within the 'vicious circle of blame' (Cadman, 2000) and emerging links with socio-technical networks. The paper then moves on to the consideration of occupier perspectives in line with corporate real estate strategies, assessing motivations, challenges and benefits associated with the occupation of sustainable buildings. Secondarily, the paper proposes avenues for further research relating to the impact of sustainability on corporate real estate strategy.

\section{Occupiers and sustainable buildings: from passive consumers to active agents}

The framing of the role of the occupier in sustainable buildings has shifted in the literature in the past 15 years. In the late 1990s, the question was focused on why - given we have the knowledge and technology - are more sustainable buildings not being built and occupied? The 'vicious circle of blame' (Cadman, 2000) suggested the answer lies in the misalignment of incentives between the providers (developers and constructors) of sustainable buildings on the one hand, and the investors and occupiers on the other. In this framework, it is argued that investors will not invest in sustainable buildings if there is no demand and, in turn, occupiers would like to have sustainable buildings but there are too few available. Subsequent studies have provided empirical evidence to support this framework, from the investor's perspective (Bond and Perrett, 2012) and the occupiers' (Van de Wetering and Wyatt, 2011). The circle of blame, is a flexible and fluid model through which the developments in sustainability literature, from the changing perspectives of both occupiers and investors can be assessed, in terms of consequences for the real estate market today. 
The circle of blame framework implies that occupiers are passive consumers in the property development process, waiting for sustainable buildings to be built that they can occupy. This has similarities with Von Hippel's early conceptualisation of 'users' in the process of innovation being passive consumers of technology, waiting patiently for manufacturers to innovate (Ivory, 2010). On the contrary, Ivory (2010) argues that users in the construction process contribute actively to design and are drivers of innovation. The extent to which they do so depends on the extent to which they are seen as technically expert, how much they will benefit from the results of innovation and the project context.

However, the role of occupiers in the sustainable property development process is not limited to their role in the development of sustainable technologies or building design. Sustainability is a social issue as well as a technological one (Rydin, 2010), and sustainable building a social as well as a physical construct (Spinks, 2015). Rydin (forthcoming) explores the role that social practices and specific calculative devices (sustainability benchmarking tools) play in constructing sustainable commercial property as a 'new market object'. Spinks (2015) also adopts a socio-technical framework for the exploration of the role of PriceWaterhouseCoopers (PwC) as tenants in the development of the UK's first BREEAM 'Outstanding' office building. This framework uses Social Network Analysis (SNA), as a tool to explore organisational and institutional dynamics, but acknowledges - drawing on Latour's work - that material elements (e.g. technologies, legislation, assessment tools etc.) can affect the relations between actors. In her case study, Spinks points to the key role of PWC as the occupier in the achievement of the building's BREEAM status. PWC "valued sustainability not only for the sake of 'doing the right thing', but also because it associated sustainable building with improved recruitment and retention costs and the communication of a corporate image" (Spinks, 2015:145). In order to achieve a highly sustainable building, PwC positioned representatives across the various stages of the development, exerting significant influence and shaping actions of others. This conceptualisation of the occupier as a "powerful actor" (ibid: 145), shaping the trajectory of sustainable commercial development, is a far cry from an understanding of occupiers as either passive consumers or participants in the process of either sustainable technological development or building design. It starts to perceive occupiers as active agents in sustainable building. The extent to which this is applicable to occupiers in general, or limited to the owneroccupier or prime market is discussed later.

Another strand of literature has assessed the occupiers' role in post-occupancy evaluation of sustainable buildings, and will be considered in more detail later. Here, the occupier's role is important as "ultimately [they] are the critics as to whether a sustainable building is considered a "success" or not" (Jailani et al, 2015: 391). Again, Jailani et al emphasise the importance of the social aspect, as occupiers' perceptions and expectations of sustainable buildings, and their knowledge of the way the building and technologies work will affect the extent to which they behave sustainably in a building. However, this literature on post-occupancy evaluation tends to conceptualise users' input as important mostly during the 'in use' phase, with feedback loops required to influence the work of designers (see Figure 3, Jailani et al, 2015, based on Jones Lang LaSalle, 2007, 'the Knowledge Cycle'). Although this approach is rather limiting, it presents an opportunity for further development into a larger scale model, which represents occupier engagement and influence throughout the design, construction (including retrofitting and redevelopment), and use of a sustainable building.

Perhaps the biggest shift in the literature has been away from the framing of the problem as one of blame towards an emphasis on cooperation and collaboration (Andelin et al, 2015). Instead of trying to 'break' the vicious cycle by, for example providing more sustainable buildings for occupiers, attention has been turned to understanding the mutual drivers and incentives for investors, developers and occupiers to build, invest in and occupy sustainable 
buildings, and exploring potential collaboration between investors (or landlords) and tenants. The next two sections will deal with these in turn.

\section{The 'business case' for green buildings: occupiers' perspectives}

In order to find ways of breaking the circle of blame, the attention of research turned to providing evidence to convince investors and developers that sustainable building makes business sense, in other words moving the rhetoric beyond 'doing good' to 'doing well'. Early literature has focused on the apparent 'value add' offered by sustainable properties and the key drivers for both investors (Falkenbach et al, 2010; Sayce et al, 2007; Pivo \& McNamara, 2005) and developers (Ang \& Wilkinson, 2008; Frej, 2005; Keeping \& Shiers, 2004). Can we really incorporate sustainable features into pricing, if so, how? What levels of financial premiums exist or is it all just 'green wash'? Is there is a willingness to pay higher rents to occupy a sustainable building and what are the benefits? These questions are not easy to answer, and the process of valuing sustainability features is also subjective and problematic due the heterogeneity of direct real estate assets. However, evidence of financial premiums relating to sustainability has expanded since Sayce's comprehensive review of market reports and literature (2010), where evidence on value premiums (Bowman \& Wills, 2008), costing (McAllister et al, 2009) and appraising sustainable buildings (De Francesco \& Levy, 2008; Fisher et al, 2008; Ellison \& Sayce, 2006), was in the early stages of development.

On examining a dataset of US commercial offices, Fuerst \& McAllister (2011b) find that there is an average rental premium of $4-5 \%$, and sales premium of $25-26 \%$, for buildings with environmental certifications. They reinforce the perspective that 'green value' to the occupier comes specifically from reduced operating costs, improved image, enhanced business performance and financial incentives. Another study of US offices by Eichholtz et al (2010), presents evidence of similar rental premiums for certified buildings at $3 \%$ (but premia of over $7 \%$ for effective rents), and a slightly lower, yet still significant sales premium of $16 \%$. A recent UK study by Fuerst \& Van de Wetering (2015) investigated the UK office market and again finds that occupiers pay a rental premium for BREEAM rated properties, which varies depending on specific property characteristics such as the certification level and the property age. Chegut at al (2014) relate the expansion of sustainable, green building to supply and demand factors in London, observing that there is an associated rental premium; however this premium diminishes in value as the number of sustainable buildings in the locality increases. On the flip side, Kok \& Jennen (2012) observe that in the Netherlands, 'inefficient' buildings with lower energy performance ratings (EPC) receive, on average, rental income which is $6.5 \%$ lower than similar 'efficient' buildings. It is now clear that value premia exist in relation to sustainable buildings, although their valuation remains challenging and complex (Lorenz \& Lützkendorf, 2011; 2008). From the perspective of the occupiers, does the rental premium provide benefits in excess of this uplift in cost?

Van de Wetering and Wyatt (2011) argue that most of the financial benefits are to the investors, in the form of higher rent or additional service charge, which raises the question: are there benefits to occupiers when leasing green space? Or framed differently, "are [green buildings] more attractive to tenants and occupiers?" (WGBC, 2013: 6). In the real estate industry, there is a growing perception that sustainability issues are of importance to occupiers - whereas two-thirds of fund managers and investors believed sustainability issues to be of importance to their occupiers in 2010, this had risen to $91 \%$ by 2014 (GVA, 2014). Why might this be?

Andelin et al (2015) distinguish between external, corporate level and property level drivers. The literature on occupiers' motivations fall primarily into the latter two categories and broadly covers three areas: (a) reduced operational costs (property-level driver), (b) enhanced 
productivity and employee well-being (corporate-level driver), and (c) reputation and brand strategy (corporate-level driver).

On reduced operating costs, Kats (2003) has shown in the US that LEED-certified green buildings' energy use is reduced by $25-30 \%$ compared to conventional buildings and that higher levels of certification correspond to higher energy savings. A similar study in New Zealand showed a reduction of up to $35-50 \%$ for green buildings and found that a higher rental premium for tenants was offset by cost savings by a factor of three (Fullbrook et al, 2006). The extent to which the occupier market is differentiated remains unexplored in these studies, but will be considered later.

However, given that businesses on average spend less than $1 \%$ of their workplace costs on energy, compared to $10 \%$ on rent and $85 \%$ on employee salaries and benefits (Persram et al, 2007); a potentially much more significant area of savings is around employee productivity and well-being. In its report, The Business Case for Green Building, the World Green Building Council (WGBC) (2013) reviews the research linking workplace productivity and building design, showing that access to daylight, views of nature, individual temperature control and other design measures can positively influence worker productivity. They also consider the evidence on indicators of health (such as absenteeism) and well-being (stress levels and mood), particularly highlighting the role of indoor air quality. It concludes:

"While there is a growing body of research and empirical evidence linking building design attributes to productivity, health, and well-being, the results of this body of research has not been well integrated into building design and there has not been a consistent method to link the outcomes to financial metrics. As result, while the evidence is there, the industry remains sceptical and continues to under-invest in the occupant experience, missing out on what is potentially its greatest return on investment." (WGBC, 2013: 74)

There is also a body of work examining the role of environmentally responsible and sustainable practices for the corporate reputation and image of real estate companies who behave 'responsibly' in line with key environmental, social and governance (ESG) factors (Cajias et al, 2014). On the whole, corporate investor perspectives dominate this literature (Barthorpe, 2010; Jones et al, 2009); take Newell, for example, who assesses the impact of portfolio sustainability on stakeholder decision making into Australian listed property trusts (2008) and Cajias et al (2012) who find a positive link between green agendas and performance for European listed real estate companies. However, from the literature, it is clear that the benefits of being environmentally responsible and adopting strong Corporate Social Responsibility (CSR) approaches benefits not only the investors and occupiers, but these benefits filter through to stakeholders such as shareholders, clients and stakeholders.

Less work has been done on the influence of occupiers' CSR agenda on their choice and management of their workplace. For investors, demonstrating an environmentally responsible and sustainable approach is important to capture the increasing interest in Responsible Property Investment (RPI), whereas for occupiers, their staff are their greatest asset. When it comes to recruiting and retaining 'the best', Hiltrop (1999) found that 'corporate pride' rather than pay is the most important factor. Similarly, Albinger and Freeman (2000) found that jobseekers with the greatest level of choice (i.e. the most talented) are more influenced by organisational CSR. Once in the green workplace, Kato et al (2009) found that the psychological benefits - e.g. taking pride in their workplace environment - were greater than the health and productivity gains, and that management perceived greater benefits of a green workplace than employees. Indeed, Paul \& Taylor's (2008) work found working in green buildings did not enhance the employee experience. However, Smith \& Pitt (2011), suggest that by adopting a sustainable building strategy, workplace productivity, as well as health 
gains, can be mutually enhanced. This discrepancy between employers and employees perception of the benefits of green offices was also revealed in a study on the impact of green offices on the health and productivity of workers in Australia (Armitage et al, 2011).

\section{'Going green': Occupiers' role in the performance of sustainable buildings}

From the extant literature it is clear that there are numerous potentially positive outcomes associated with green, highly rated, sustainable building which offer both 'direct and indirect financial benefits for investors, occupiers and other stakeholders' (Dixon et al, 2009: 64). It is also evident that there is both a demand for, and a willingness to pay from occupiers (Zieba et al, 2013), to access such buildings. For many occupiers, sustainable features are a key influence on their decision making relating to how they manage their corporate real estate interests. However, location remains the key influence on occupiers. Other factors found to take precedence over sustainability in decision making are reflected in a number of studies. Availability and building quality (Dixon et al, 2009) as well as the flexibility and accessibility of the building (Van de Wetering and Wyatt, 2011), are prioritised by occupiers, and the less prominent, yet additional cost of occupying a sustainable building is not viewed as a deterrent. Fuerst \& McAllister (2009) find that occupancy rates in the US for LEED rated offices are approximately $8 \%$ higher when compared to non-rated buildings. In New Zealand, the rental premium for sustainable buildings was not seen as unreasonable or unfair by occupiers (Levy \& Peterson, 2013). Sustainability is clearly emerging as an influential factor for occupiers when considering which buildings to occupy, but other real estate market factors such as location, availability and accessibility remain of paramount importance. However, once the occupier is installed in a sustainably building, what is their role as 'inhabitants' (Brown \& Cole, $2009 ; 228$ ) and how do they ensure that they maximise the benefits such buildings offer?

Through the literature there has been a realisation that in terms of occupier experience, there is a need to focus on performance, not just design (Jones Lang LaSalle, 2012). Landlord tenant relationships are important to ensure explicit communication of key sustainable features of the building, to manage expectations in relation to knowledge and performance (Jailani et al, 2015). Although guidance on the adaptation of so-called 'green leases' (IPF, 2009, Hinnells et al, 2008), of varying 'shades' of detail, and Memorandums of Understanding (MoU), have become more commonplace between landlords and tenants / investors and occupiers, their interpretation is subjective (Hinnells et al, 2008) and the nuances of these relationships are yet to be fully explored. There is a need for transparency and co-ordination between the various market actors involved, to ensure that further barriers are not created which negatively affect the occupier experience of sustainable buildings. As Warren-Myers comments, it is questionable whether 'the level of implementation of sustainability is actually achieving sustainability objectives through the management of real estate' (2012b; 177). Just because a sustainable building is occupied, it does not hold that the building will be managed and used in a sustainable way day to day. Jailani et al (2015) suggest the need for a feedback loop and open communication, to develop user knowledge regarding maximising building performance. Indeed, Armitage et al (2011) observe a clear corollary between the level of knowledge users had about a sustainable building and their satisfaction as occupants.

Although CSR has become increasingly important to all market actors engaged in corporate real estate, some occupiers may care less about the day to day performance of the building and more about the image occupying a sustainable building projects. However, as Rashid et al (2012) note, where there is non-engagement with the building, you may have a green building with 'gray' occupants, where the occupant focus is 'primarily on technology and materials to the exclusion of social and psychological mechanisms at work in the organisation' (2012: 25). This non-engagement or 'graying', may be improved by emphasising the occupier 
value in remaining aware of how the sustainable features of the building can be assessed, such as through BREEAM In Use and EPCs. In this respect, occupiers can encourage sustainable performance on a day to day basis by effectively and continually communicating the positives of sustainable occupation to all users. In the real estate industry specifically, Ellison \& Brown (2011) discuss the need for increased clarity through a framework based on sustainability metrics, to inherently assess performance in a complete way. It would seem that from the literature available, more needs to be done to demonstrate best practice for occupiers, as proactive inhabitants, in line with effective communication from landlords and investors, to prevent the 'graying' of commercial buildings, at the expense of the TBL.

\section{Sectors, contexts and markets: Future research directions.}

This final section of the work draws together the key points from the paper and offers concluding thoughts. It also reflects briefly on a variety of nuances in occupier relationships, which are beginning to emerge as important within the industry for further development, or have not been considered in detail here. How we can account for the 'value' of sustainability in appraisals remains an ongoing challenge, as does accurately ascertaining the appropriate rental / sale value premium a building can demand and how environmental performance is subjectively interpreted. Such assessments are central to occupiers' real estate decision making when they assess their 'willingness to pay' for sustainable features, competition in the market, their CSR and more importantly, their employee experience and building location. In addition to this, the more active role which occupiers can play is emerging as a burgeoning research area, which reflects how building performance can be maximised, while costs are minimised, in an environment where communication between users, management and landlords/investors is more explicit, to the benefit of all market actors involved. In accordance with the recommendations provided by the WGBC, the occupier experience and a more comprehensive framework for understanding occupier responses to sustainable buildings requires more investment and attention. Sustainability in the real estate market is clearly an area of burgeoning research development, as occupiers and investors adapt their TBL and adjust their real estate approaches to counterbalance the 'circle of blame' phenomenon.

In the course of this review, four topics of interest were identified as emerging research areas from both corporate real estate management and sustainability perspectives. The first relates to the differences between occupiers and the different challenges encountered in relation to whether a building is single or multi-tenanted, or larger / smaller occupiers (Van de Wetering \& Wyatt, 2011). Several other papers also commented on the differences between the various sectors such occupiers represented (Dixon et al, 2009), commenting that 'the importance of CREM to company sustainability varies in different industries, depending on what is the focus area of a particular business' (Masalskyte et al, 2014: 132). Such occupier perspectives add an additional dimension for further investigation, which is currently underdeveloped.

The second topic, which has seen slightly more attention in line with developers and investors, is the sustainable adaptation, redevelopment or retrofitting of real estate (Morrissey et al, 2014; Wilkinson, 2012; Schwede et al, 2008; Wilkinson et al, 2009; Bullen, 2007). Although there is a little work relating to occupiers, Miller \& Buys (2008) concluded that for tenants, sustainability was an abstract concept, and was also linked to the size of the organisation in the building. Work in this area could be combined with that of the first topic, to offer a blended representation of the influence of tenant in the process of not just occupation, but retrofitting and redevelopment. The third topic concerns linking sustainability with non-prime real estate, considering it is implicitly associated with the management and occupation of prime real estate only. The growth of sustainable real estate dominates specific markets (i.e. prime, offices in London, see Oyedokun et al, 2015), and the relationship between sustainable property at the 
non-prime level offers an opportunity for conceptualisation and further investigation (Rydin, forthcoming).

The fourth and final topic which is likely to attract further investigation relates to the emergence of sustainability from the perspective of retailers, a subject which has drawn some attention in recent years, in relation to retail best practice (Newell, 2009), sustainable real estate strategy (Thompson, 2007), green leasing (Bright et al, 2015) and the influence of sustainability on retail rents and values (Op't Veld, 2014). It is likely that this sector will receive increased consideration, as the retail market adjusts to structural changes, driven by online retailing, multi-channelling and changing consumption patterns. There is significant scope to evaluate occupier strategies and the burgeoning influence of sustainability on real estate retail management looking to the future.

\section{References}

Albinger, H., and Freeman, S. (2000) 'Corporate Social Performance and attractiveness as an employer to different job seeking populations'. Journal of Business Ethics, Vol.28, No.3, pp.243-253

Andelin, M., Sarasoja, A., Ventovuori, T. \& Junnila, S. (2015) "Breaking the circle of blame in sustainable buildings: Evidence from Nordic countries". Journal of Corporate Real Estate, Vol. 17, No.1, pp.26-45.

Ang, S.L. \& Wilkinson, S.J. (2008) "Is the social agenda driving sustainable property development in Melbourne, Australia". Property Management. Vol.25, No.5, pp.331-343.

Armitage, L., Murugan, A. \& Kato, H. (2011) "Green offices in Australia: a user perception survey'. Journal of Corporate Real Estate, Vol.13, No.3, pp.169-180.

BBP (2013) “Green lease toolkit”, BBP, London.

BBP (2012) "Sustainability benchmarking toolkit for commercial buildings: principles for best practice", BBP, London.

Bond, S. \& Perrett, G. (2012) "The Key Drivers and Barriers to the Sustainable Development of Commercial Property in New Zealand". Journal of Sustainable Real Estate, Vol.4, No.1, pp. 45-77.

Bowman, R. \& Wills, J. (2008) "Valuing Green. How green buildings affect property value and getting the valuation method right". Green Building Council: Melbourne.

Bright, S., Patrick, J., Thomas, B., Janda, K.B., Bailey, E., Dixon, T. \& Wilkinson, S. (2015) "The evolution of 'greener' leasing practices in Australia and England", paper presented at RICS COBRA AUBEA 2015, 8-10 July, Sydney, Australia, available at: http://www.rics.org/uk/knowledge/research/conference-papers/the-evolution-of-greenerleasing-practices-in-australia-and-england/ (accessed 03/03/2016).

Brown, Z. \& Cole, R.J. (2009) "Influence of occupant's knowledge on comfort expectations and behaviour". Building Research \& Information, Vol.37, No.3, pp.227-245.

Brundtland, G. H. (1987) "Our Common Future: World Commission on Environment and Development", Oxford University Press, Oxford.

Bullen, P.A. (2007),"Adaptive reuse and sustainability of commercial buildings". Facilities, Vol. 25, No.1/2 pp. 20-31. 
Cadman, D. (2000) "The vicious cycle of blame", cited in Keeping, M. (2000) "What about demand - do investors want sustainable buildings?" RICS, London.

Cajias, M., Fuerst, F., McAllister, P. \& Nanda, A. (2014) "Do responsible real estate companies outperform their peers?" International Journal of Strategic Property Management, Vol.18, No.1, pp.11-27.

Cajias, M., Geiger, P. \& Bienert, S. (2012) "Green agenda and green performance: empirical evidence from real estate companies". Journal of European Real Estate Research, Vol.5, No.2, pp. 135-155.

Chegut, A., Eichholtz, P. \& Kok, N. (2014) "Supply, demand and the value of green buildings." Urban Studies, Vol.51, No.1, pp.22-43.

De Francesco, A. \& Levy, D. (2008) "The Impact of Sustainability on the Investment Environment: A Case Study of Australia". RICS, London.

DeLisle, J., Grissom, T. \& Högberg, L. (2013),"Sustainable real estate". Journal of Property Investment \& Finance, Vol. 31, No.1, pp. $10-40$.

Dixon, T., Colantonio, A., Shiers, D., Reed, R., Wilkinson, S. \& Gallimore, P. (2008) "A green profession? A global survey of RICS members and their engagement with the sustainability agenda". Journal of Property Investment \& Finance, Vol.26, No.6, pp.460-481.

Dixon, T., Ennis-Reynolds, G., Roberts, C. \& Sims, S. (2009) "Is there a demand for sustainable offices? An analysis of UK business occupier moves (2006-2008)". Journal of Property Research, Vol.26, No.1, pp.61-85.

Eichholtz, P. M. A., Kok, N. and Quigley, J. M. (2010) "Doing well by doing good: green office buildings". American Economic Review, Vol.100, pp. 2494-2511.

Ellison, L. \& Brown, P. (2011) "Sustainability metrics for commercial real estate assets establishing a common approach". Journal of European Real Estate Research. Vol.4, No.2, pp.113-130.

Ellison, L. \& Sayce, S. (2006) "The Sustainable Property Appraisal Project”. Kingston University.

Elkington, J. (1997) "Cannibals with Forks: The Triple Bottom Line of $21^{\text {st }}$ Century Business". Capstone Publishing Limited, Oxford.

Falkenbach, H., Lindholm, A. \& Schleich, H. (2010) "Environmental Sustainability: Drivers for the Real Estate Investor". Journal of Real Estate Literature, Vol. 18, No.2, pp.203-233.

Fisher, R., Coll, L., Pelly, L. \& Percy, J. (2008) "Surveying Sustainability: A Short Guide for the Property Professional". The Appraisal Journal, Winter 2008, pp.15-22.

Frej, A. (2005) "Green office buildings: A practical guide to development." ULI, Washington D.C.

Fuerst, F. \& P. McAllister. (2009) "An Investigation of the Effect of Eco-Labeling on Office Occupancy Rates." Journal of Sustainable Real Estate, Vol.1, No.1, pp. 49-64.

Fuerst, F. \& McAllister, P. (2011a) "The impact of Energy Performance Certificates on the rental and capital values of commercial property assets". Energy Policy, Vol.39, pp.66086614. 
Fuerst, F. \& McAllister, P. (2011b) "Green Noise or Green Value? Measuring the effects of environmental certification on office values". Real Estate Economics, Vol.39, No.1, pp. 4569.

Fuerst, F. \& Van de Wetering, J. (2015) "How does environmental efficiency impact on the rents of commercial offices in the UK?" Journal of Property Research, Vol.32, No.3, pp.193216.

Fullbrook, D., Jackson, Q., \& Finlay, G. (2006). "Value case for sustainable building in New Zealand." Report for the Ministry for the Environment, New Zealand, Wellington: Ministry for the Environment.

GRESB (2015) “2015 GRESB Report”, Global Real Estate Sustainability Benchmark, GRESB V.B., Amsterdam.

GVA (2014) "Green to Gold." GVA London.

Haapio, A. \& Viitaniemi, P. (2008) "A critical review of building environmental assessment tools". Environmental Impact Assessment Review, Vol.28, No.7, pp.469-482.

Hinnells, M., Bright, S., Langley, A., Woodford, L., Schiellerup, P. \& Bosteels, T. (2008) "The Greening of Commercial Leases", Journal of Property Investment and Finance, Vol 26, No.6, pp. 541-555.

Hiltrop, J. (1999) 'The Quest for the Best: Human resource practices to attract and retain talent'. European Management Journal, Vol. 17, No.4, pp.422-430

IPF (2009) "Greening Leases: The landlord tenant relationship as a driver for sustainability." IPF, London.

Ivory, C. (2010) "Client, User and Architect interactions in Construction: Implications for analysing innovative outcomes from user-producer interactions in projects". Technology Analysis and Strategic Management, Vol.16, No.4, pp.495-508.

Jailani, J., Reed, R. \& James, K. (2015) "Examining the perception of tenants in sustainable office buildings". Property Management. Vol.33, No.4, pp.386-404.

Janda, K.B, Bright, S., Patrick, J., Wilkinson, S., Dixon, T.J. (2016) "The evolution of green leases: towards inter-organizational environmental governance'. Building Research and Information. Online: March $1^{\text {st }} 2016$.

Jones Lang LaSalle (2012) "A tale of two buildings". JLL/Building Better Partnership, London.

Jones, P., Hillier, D., Comfort, D. \& Clarke-Hill, C. (2009) "Commercial property investment companies and corporate social responsiblity". Journal of Property Investment \& Finance, Vol.27, No.5, pp. 522-533.

Kato, H., Too, L., \& Rask, A. (2009) 'Occupier perceptions of green workplace environment: the Australian experience'. Journal of Corporate Real Estate, Vol.11, No.3, pp183-195.

Kats, G. (2003) "The Costs and Benefits of Green: A Report to California's Sustainable Building Task Force". Capital E Analytics, Washington DC. 
Keeping, M. \& Shiers, D.E. (2004) Sustainable Property Development, Blackwell Science Limited, Oxford.

Kok, N. \& Jennen, M. (2012) "The impact of energy labels and accessibility on office rents." Energy Policy, Vol.46, pp. 489-497.

Levy, D. \& Peterson, G. (2013) "The effect of sustainability on commercial occupiers' building choice". Journal of Property Investment \& Finance. Vol.31, No.3, pp.267-284.

Lorenz, D \& Lützkendorf, T. (2011),"Sustainability and property valuation: Systematisation of existing approaches and recommendations for future action". Journal of Property Investment \& Finance, Vol. 29, No.6, pp. 644-676.

Lorenz, D. \& Lützkendorf, T. (2008),"Sustainability in property valuation: theory and practice", Journal of Property Investment \& Finance, Vol. 26, No. 6 pp. $482-521$.

Masalskyte, R., Andelin, M. \& Sarasoja, A. (2014) "Modelling sustainability maturity in corporate real estate management". Journal of Corporate Real Estate, Vol.16, No.2, pp.126139.

McAllister, I., Quartermaine, R. \& McWilliams, F. (2009) “Costing Energy Efficiency Improvements in Existing Commercial Buildings". IPF, London.

Miller, E. \& Buys, L. (2008),"Retrofitting commercial office buildings for sustainability: tenants' perspectives". Journal of Property Investment \& Finance, Vol. 26, No.6 pp. 552 561.

Morrissey, J., Dunphy, N. \& MacSweeney, R. (2014),"Energy efficiency in commercial buildings: capturing added-value of retrofit". Journal of Property Investment \& Finance, Vol. 32, No.4 pp. 396-414.

Newell, G. (2008) "The strategic significance of environmental sustainability by Australianlisted property trusts". Journal of Property Investment \& Finance, Vol.26, No.6, 522-540.

Newell, G. (2009) "The significance of sustainability best practice in retail property". Journal of Retail and Leisure Property, Vol.8, No.4, pp.259-271.

Op't Veld, H., \& Vlasveld, M. (2014) "The effect of sustainability on retail rents, values and investment performance: European Evidence”. Journal of Sustainable Real Estate, Vol.6, No.1, pp.163-185.

Oyedokun, T.B., Jones, C.A., \& Dunse, N. (2015) "The growth of the green office market in the UK". Journal of European Real Estate Research, Vol.8, No.3, pp.267-284.

Paul, W.L. \& Taylor, P.A. (2008) "A Comparison of Occupant Comfort and Satisfaction between a Green Building and a Conventional Building". Building and Environment, Vol, 43, pp.1858-1870.

Persram, S., Lucuik, M. \& Larsson N. (2007) "Marketing Green Buildings to Tenants of Leased Properties." Canada Green Building Council.

Pivo, G. \& McNamara, P. (2005) "Responsible property investing". International Real Estate Review, Vol 8, No 1, pp. 128-143. 
Rashid, M., Spreckelmeyer, K. \& Angrisano, N.J. (2012) "Green buildings, environmental awareness, and organizational image". Journal of Corporate Real Estate, Vol.14, No.1, pp.21-49.

REESTI (2014) "Real estate environmental sustainability index", JLL, London.

RICS (2009) "Sustainability and the RICS property lifecycle", $1^{\text {st }}$ edition. RICS, London.

RICS (2013a) "Sustainability and commercial property valuation", $2^{\text {nd }}$ edition, RICS, London.

RICS (2013b) "Sustainability: Improving performance in existing buildings", $1^{\text {st }}$ edition (UK), RICS, London.

RICS (2014) “Measuring 'Green Value': An International Perspective”, RICS, London.

Rydin, Y. (2010) "Governing for sustainable development". London: Earthscan.

Rydin, Y. (forthcoming) "Sustainability and the financialisation of commercial property: making prime and non-prime markets." Environment \& Planning D.

Sayce, S. (2010) "Is sustainability reflected in commercial property prices: An analysis of the evidence base". RICS Report, London.

Sayce, S., L. Ellison, \& P. Parnell. (2007) "Understanding Investment Drivers for U.K. Sustainable Property." Building Research and Information, Vol.35, No.6, pp. 629-643.

Schwede, D.A., Davies, H. \& Purdey, B. (2008) "Occupant satisfaction with workplace design in new and old environment." Facilities, Vol.26, No.7/8, pp.273-288.

Shiers, D.E. (1999) “'“Green” Developments-Environmentally Responsible Buildings in the U.K. Commercial Property Sector." Property Management, Vol.18, No.5, pp.352-365.

Smith, A. \& Pitt, M. (2011) "Sustainable workplaces and building user comfort and satisfaction". Journal of Corporate Real Estate. Vol.13, No.3, pp.144-156.

Spinks, M. (2015) "Understanding and auctioning BRE environmental assessment method: a socio-technical approach". Local Environment, Vol.20, No.2, pp.131-148.

Thompson, B. (2007) "Green Retail: Retailer strategies for surviving the sustainability storm". Journal of Retail and Leisure Property, Vol.6, No.4, pp.281-286.

Van de Wetering, J. \& Wyatt, P. (2011) "Office sustainability: occupier perceptions and implementation of policy". Journal of European Real Estate Research, Vol.4, No.1, pp.29-47.

Vimpari, J. \& Junnila, S. (2014) "Value influencing mechanism of green certificates in the discounted cash flow valuation", International Journal of Strategic Property Management, Vol.18, No.3, pp.238-252.

Warren-Myers, G. (2012a),"The value of sustainability in real estate: a review from a valuation perspective", Journal of Property Investment \& Finance, Vol. 30, No. 2 pp. 115144.

Warren-Myers, G. (2012b) "Sustainable management of real estate: Is it really sustainability?" Journal of Sustainable Real Estate, Vol. 4, No.1, pp.177-197.

Wilkinson, S. (2012),"Analysing sustainable retrofit potential in premium office buildings", Structural Survey, Vol. 30, No. 5 pp. 398-410. 
Wilkinson, S. (2015) "Conceptual Understanding of Sustainability in Built Environment Professionals". ZEMCH (Zero Energy Mass Custom Home) Network Conference, 21-25 September, Barre, Italy.

Wilkinson, S.J., James, K. \& Reed, R. (2009) "Using building adaptation to deliver sustainability in Australia". Structural Survey. Vol.27, No.1, pp.46-61.

World Green Business Council (WGBC) (2013) "The Business Case for Green Buildings: A Review of the Costs and Benefits for Developers, Investors and Occupiers". WGBC.

Available online at: www.worldgbc.org

Zieba, M., Belniak, S. \& Gluszak, M. (2013) "Demand for sustainable office space in Poland: the results from a conjoint experiment in Krakow". Property Management, Vol.31, No.5, pp.404-419. 